\title{
Effects of Semantic and Syntactic Complexities and Aspectual Class on Past Tense Production
}

\author{
Ayumi Matsuo \\ Max Planck Institute for Psycholinguistics \\ Ayumi.Matsuo@mpi.nl
}

\begin{abstract}
This paper reports results from a series of experiments that investigated whether semantic and/or syntactic complexity influences young Dutch children's production of past tense forms. The constructions used in the three experiments were (i) simple sentences (the Simple Sentence Experiment), (ii) complex sentences with CP complements (the Complement Clause Experiment) and (iii) complex sentences with relative clauses (the Relative Clause Experiment). The stimuli involved both atelic and telic predicates. The goal of this paper is to address the following questions.

Q1. Does semantic complexity regarding temporal anchoring influence the types of errors that children make in the experiments? For example, do children make certain types of errors when a past tense has to be anchored to the Utterance Time (UT), as compared to when it has to be anchored to the matrix topic time (TT)?

Q2. Do different syntactic positions influence children's performance on past-tense production? Do children perform better in the Simple Sentence Experiment compared to complex sentences involving two finite clauses (the Complement Clause Experiment and the Relative Clause Experiment)? In complex sentence trials, do children perform differently when the CPs are complements vs. when the CPs are adjunct clauses? (Lebeaux 1990, 2000)

Q3. Do Dutch children make more errors with certain types of predicate (such as atelic predicates)? Alternatively, do children produce a certain type of error with a certain type of predicates (such as producing a perfect aspect with punctual predicates)? Bronckart and Sinclair (1973), for example, found that until the age of 6, French children showed a tendency to use passé composé with perfective events and simple present with imperfective events; we will investigate whether or not the equivalent of this is observed in Dutch.
\end{abstract}

\section{$1 \quad$ Introduction}

In this paper, we will investigate whether syntactic and/or semantic complexity influences past tense production by young Dutch speaking children. The sentences with past tense forms are of our interest because a past tense displays various semantic complexities that a present tense does not. For example, when a past tense appears in a complex sentence as in (1) (we call (1) PAST UNDER PAST SENTENCES following Abusch (1988)), there are two interpretations available depending on how the past tense is anchored (see Section 2 for more details):

(1) past under past sentences

A monkey said that a girl had red hair.

(1) can be a paraphrase of either (2a) or (2b): 
(2) a. $\quad$ A monkey said "a girl had red hair."

b. $\quad$ A monkey said "a girl has red hair."

We call (2a) a real past reading and (2b) an overlapping reading. In (2a), the Topic Time (TT) (Klein 1994) of the girl having red hair does not overlap but precedes the TT of the monkey saying so. The TT of the girl having red hair is the time for which the claim that the girl having red hair was made (Klein 1994). In (2b) two TTs overlap with each other. We may contrast (1) with the sentence in (3), where a present tense appears in the complex sentence. Here, things are more straightforward because a present tense is always understood with respect to the Utterance Time (UT).

(3) A monkey said that a girl has red hair.

(3) is about a girl still having red hair at the UT.

Although there has been a vast amount of research on the acquisition of Tense and Aspect, much less has been published on the interaction of two finite predicates (see Hickmann (1993) and Hollebrandse (1999)). This is partly because previous research had a different focus, such as the emergence of past tense morphology, which is first found in one-word or two-word utterances (see the well-known debates on the Primacy of Aspect Hypothesis and Lexical Aspect Before Tense Hypothesis). This paper aims to investigate issues that go beyond past tense morphology; namely, how a past tense is actually introduced. To succeed in these experiments, children must know whether or not a past tense has to be interpreted with respect to the UT in certain syntactic positions but with respect to the time point introduced by matrix finite predicates in other positions. The results of this study will cast light on what factors influence the production of a past tense form by young children. We aim to find out whether or not it is syntactic complexity that interferes with children's production, or whether it is anchoring the TT to other temporal points that is difficult for the children, or a combination of the two.

Bowerman (1979) claims that the ability to produce complex sentences in English emerges between the ages of 2 to 4 (stage IV-MLU from 3-3,5). A brief inspection of the CHILDES database (MacWhinney and Snow (1990)) below shows that utterances involving two predicates first appear around age 3;2 for Adam, 2;3 for Eve, and not until 4;6 for Sarah.

(4) Early complex sentences by Adam ${ }^{1}$

a. $\quad$ CHI: what me think? (adam15.cha: line 992) $(2 ; 10.2)$

b. $\quad$ CHI: what he xxx name \# <I> [/] I think? (adam18.cha: line 37) $(2 ; 11.13)$

c. $\quad$ CHI: what me \# think \# looking? (adam18.cha: line 997)

d. $\quad$ CHI: I going make a trailer \# I think. (adam20.cha: line 256) $(3 ; 0.11)$

e. $\quad$ CHI: I think I will use dis color. (adam25.cha: line 1960) $(3 ; 2.21)$

(5) Early complex sentences by Eve

a. $\quad$ CHI: I think \# in the basket. (eve 08: line 4864) (1;9)

b. $\quad$ CHI: I think \# in dolly bed.

c. CHI: Mamma think downstairs.

d. CHI: I think that good enough. (eve 12: line 1447) $(1 ; 11)$

e. $\quad$ CHI: I think it going round now. (eve 12: line 2626) $(1 ; 11)$

Combo search was conducted using other propositional verbs such as say, tell but think was the most frequently used verb and it also appeared earliest in the database so I report the data involving think. 
f. $\quad$ CHI: I think I have tear one and I think I can write one. (eve 19: line 633) $(2 ; 3)$

g. $\quad$ CHI: I think we have the rest of it in here. (eve 19: line 1702)

(6) Early complex sentences by Sarah

a. $\quad$ CHI: I think somebody found it. (sarah 118; line 50) $(4 ; 6.17)$

b. $\quad$ CHI: I think I gettin(g) a pretty good job. (sarah 118; line 564)

c. $\quad$ CHI: I think I got it now. (sarah 118; line 833)

d. CHI: but \# I think when I grow up I will \# go on tv. (sarah 119; line 834) (4;7.24)

The CHILDES data above suggest that children display various types of errors when they start producing complement clauses with intensional verbs. Many ungrammatical sentences are found in (4) to (6). Notably, Adam appearsto treat think as though it takes a non-finite complement. In (4c) and (4d), for example, progressive participles (looking and going) are used with think. Grammatical sentences (4e) with two finite predicates are first found at age 3;2. Eve makes similar types of errors. At age 1;9, she produces ungrammatical sentences, combining think with a locative PP (see (5a), (5b) and (5c) with an adverbial). She also produces a complement clause with a progressive participle: see going in (5e). Sarah's first use of an intensional verb with a complement is not until 4;6 when she uses it correctly (see (6a)). However, this is followed in (6b) by the same error that was made by Adam and Eve; namely, a complement clause with a progressive participle: getting.

There are several possible explanations as to why all three children produce non-finite verbs as complements of think. First, this might be an overgeneralization error where children apply an incorrect argument structure to the verb think. It is conceivable that these children are incorrectly applying the argument structure of one of the early verbs: look (at), to the verb think. Tomasello (1992) reports that his daughter produced the following sentences at age $1 ; 8.04(232 ; 1992)$ :

(7) a. Look Weezer climbing a tree.

b. Look at girl drinking a Kool-aid.

Related to the subcategorization error is the case in (8), which Banfield (1984) discusses. As shown in (8), the embedded clause with say does not necessarily include obligatory finite markings.

(8) John said to go. (p.71; Banfield (1984))

A sentence such as (8) in the input might facilitate children's production errors. It might be possible that children first set their grammar to use finite and infinite predicates interchangeably in embedded clauses. This speaks to the errors such as (4c), (5e) and (6b).

Second, it might be the case that these children omit the be-auxiliaries in progressive constructions. If this were the case, we would expect children to use correct finite predicates when a complement clause contains a simple tense without any auxiliaries. ${ }^{2}$

Third, it might be that embedded sentences also show an influence of the (lexical) Aspect before Tense Hypothesis. It is well known that children's first utterances include either no verbs or include only non-finite verbs (Antinucci and Miller (1976), Bloom et al. 1980, Olsen and Weinberg(1998), Shirai and Andersen (1995) among others). It is reported that children initially use a perfective marker with the predicates that describe events with clear results,

2 This point was raised by Melissa Bowerman (p.c. July $2^{\text {nd }}, 2002$ ). 
whereas they use a progressive marker with predicates without any clear end points. In Bronckart and Sinclair (1973), it is shown that this trend even lasts until 6 years old. In the CHILDES data above, the embedded predicates where Adam, Eve and Sarah use the progressive participles are restricted to atelic predicates; hence, it is conceivable that the Aspect before Tense Hypothesis applies to a complement clause, too.

Given the scarcity of relevant utterances in CHILDES, the following elicited production experiments were conducted to investigate whether children produce ungrammatical embedded predicates, and if so, what factors (semantic and/or syntactic complexity or Lexical Aspect) contribute to these errors. An elicited production task was the methodology chosen here to carefully control the environment where the past tense predicates should occur; such as, in a simple sentence, in a complement clause and in a relative clause.

\section{Semantic, Syntactic and Lexical factors}

In this section, we will discuss the three formal factors (semantic, syntactic and lexical) that can potentially influence children's performance in the experiments.

The first factor is the semantic complexity that is related to temporal interpretations of past tense discussed in Klein (1994), Enç (1987) and Stowell (1996). Klein (1994), modifying the traditional Reichenbachian approach, argues that Tense always determines the relationship between the TT and the UT; for example, a past tense calls for a TT to be placed prior to the UT. In interpreting one of the stimuli used in The Simple Sentence Experiment (in (9)), children have to know that the TT of the flying must precede the UT. The TT of the flying in (9) is the time for which the claim that flying took place was made (Klein 1994).

\section{(9) Simple sentence}

The cat flew.

The complex sentences used in the Complement Clause Experiment and the Relative Clause Experiment, however, involve more complex temporal structures. Examples (10) and (12) are the English equivalents of the Dutch test sentences used in the experiments:

(10) Complement Clause (past under past sentences)

The monkey said that the girl baked a cake ${ }^{3}$. (real past reading)

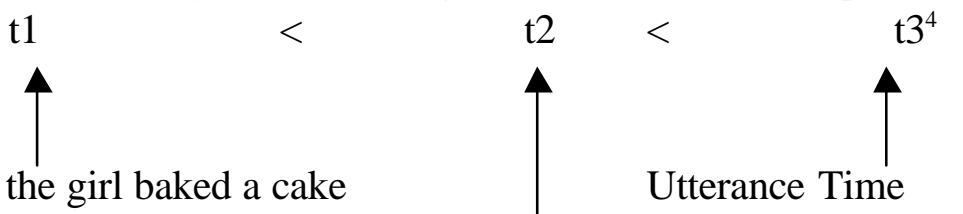

(TT2) the monkey said that the girl baked a cake

(TT1)

3 In English, this sentence involving a telic predicate such as bake a cake is different from the sentence where an atelic predicate is used such as in (i):

(i) The monkey said that the girl was sad.

In (10), the target state where the girl finished baking a cake is reached within TT2 (Klein 40; 1994); however, when a predicate is atelic as in (i), it is unclear whether the target state is reached or not. It is possible that the girl is still sad at the UT.

4 Three temporal points are indicated as $\mathrm{t} 1, \mathrm{t} 2$ and $\mathrm{t} 3$. 
In (10), there are two TTs. One is the TT of the monkey making a remark (about the girl baking a cake) and the other is the TT of the girl baking a cake. We call them TT1 and TT2 respectively. The first past tense (in said) positions the TT1 prior to the UT and the second past tense in baked also positions the TT2 prior to the UT. However, what is crucial here is that there should be an ordering restriction between TT1 and TT2. In (10), TT2 must precede TT1; we call this a real past reading. Such an ordering restriction is discussed in detail in Enç (1987) and Stowell (1996); only the relevant aspects of the mechanism will be discussed below. Before turning into a temporal mechanism, we need to note that there is another reading for the English PAST UNDER PAST SENTENCE when the embedded predicate is stative as shown in (1) repeated here in (11):

Complement clause (PAST UNDER PAST SENTENCES, stative)

A monkey said that a girl had red hair. (overlapping reading)

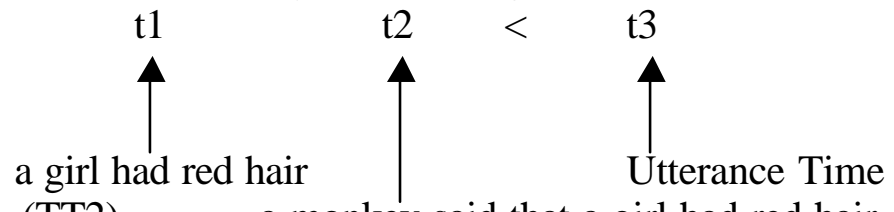

(TT2) a monkey said that a girl had red hair (TT1)

(11) can have a reading where TT1 and TT2 overlap (called an overlapping reading). There is a cross-linguistic variation in whether or not PAST UNDER PAST SENTENCES allow an overlapping interpretation as in (11). The languages which allow embedded past to display an overlapping interpretation are called Sequence of Tense (SOT) languages.

Among SOT languages, there are two types. In one type, such as in English, an overlapping interpretation is restricted to the case where the embedded predicate is stative (see (11)). The other type, such as in Dutch, no such restriction is observed. A Dutch counterpart of (10), shown in (12), is ambiguous between a real past and an overlapping readings. This is because Dutch simple past is equivalent to both past progressive and simple past in English.

(12) De aap zei dat het meisje een taart bakte.

the monkey said that the girl a cake baked

'The monkey said that the girl baked a cake.'

(12) has an overlapping reading where the monkey said that the girl was baking a cake and a real past reading where the monkey said that the girl had baked a cake.

There are also languages that do not allow an embedded past tense to exhibit an overlapping interpretation at all. These languages are called 'non-SOT languages' and in these languages, a present tense is used instead of a past tense to represent the overlapping interpretation. The SOT phenomenon will be discussed more later in the paper.

Returning to the various interpretations of PAST UNDER PAST SENTENCES, Enç (1987) accounts for the ordering restriction of the real past interpretation (discussed in (13), using the theory of Government and Binding, in terms of indices. Index 0 refers to the UT and the matrix past has index $\mathrm{i}$, which refers to the point that precedes the UT. The embedded COMP is bound by the (co-indexed) matrix tense and the embedded past has index $\mathrm{j}$, which precedes the temporal point represented by index $i$. The co-indexed embedded COMP makes sure that the embedded past (j) refers to a point that precedes (i):

(13) $\left[\mathrm{Comp}_{0}\left[\mathrm{NP}\left[\mathrm{PAST}_{\mathrm{i}}\left[\mathrm{V}\left[\mathrm{Comp}{ }_{\mathrm{i}}\left[\mathrm{NP}\left[\mathrm{PAST}_{\mathrm{j}} \ldots \quad\right.\right.\right.\right.\right.\right.\right.$ Enç $(644 ; 1987)$ 
Matters are different in sentence (14), one of the stimuli used in the Relative Clause Experiment. In (14), there is no ordering restriction between TT1 and TT2; (14) thus yields a so-called independent reading.

(14) Relative clause

A monkey saw a girl who baked a cake. (independent reading)

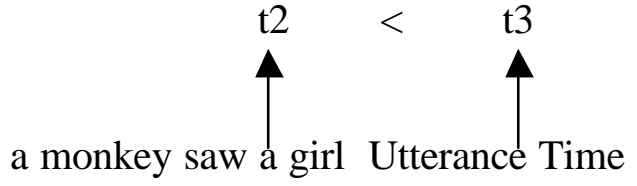

(TT1)

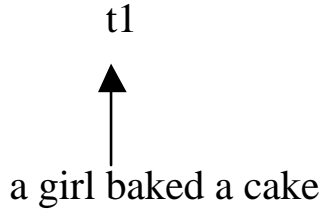

(TT2)

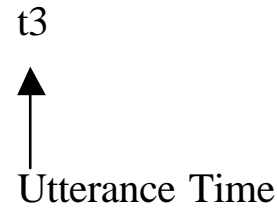

In (14), TT1 can be either before or after TT2 as long as they are both placed in the past with respect to the UT. In Enç's theory, the independent reading is represented as in (15):

(15) $\left[\right.$ Comp $_{0}\left[\mathrm{NP}\left[\mathrm{PAST}_{\mathrm{i}}\left[\mathrm{V}\left[\mathrm{NP}\left[\mathrm{Comp}_{0}\left[\ldots \mathrm{PAST}_{\mathrm{j}}\right.\right.\right.\right.\right.\right.$ (independent)(Enç (1987))

In (15), two Comps have index 0 that refers to the UT and two past tenses refer to the points that are past with respect to the UT. The adjoined COMP, which is indexed as 0 , cuts the dependency between two past tenses. It is said that the predicate in the relative clause in (14) and (15) behaves as if it is in a simple sentence and not embedded. Compare (15) with (17):

(16) John died.

(17) $\left[\mathrm{Comp}_{0}\left[\mathrm{NP}\left[\mathrm{PAST}_{\mathrm{i}}[\mathrm{VP}(\mathrm{Enç}(1987))\right.\right.\right.$

Notice that both in (15) and (17), Comp has an index 0, which refers to the UT $(644 ; 1987)$. The past tense has an index $\mathrm{i}$, which can refer to any point in the past with respect to the Utterance Time (0).

An alternative analysis is presented in Stowell (1996); Stowell proposes that tense phrases (called ZP in his paper) have a pronominal specifier (called PRO-ZP), which has to be controlled by tense bearing elements. In Stowell (1996), different control possibilities correspond to different temporal interpretations. For example, (10) is distinguished from (14) by a syntactic movement (Quantifier Raising of QPs or NPs). PAST UNDER PAST SENTENCES as in (10) cannot have an independent interpretation because they do not include any NPs that can undergo LF movement. The CP argument of an intensional verb always stays in situ; hence, the embedded PRO-ZP is always controlled by the matrix past tense, yielding a real past reading where TT2 precedes TT1. (14), on the other hand, receives an independent reading when the NP undergoes an LF movement, pied-piping the relative clause. After the movement of an NP to a matrix $\mathrm{CP}$, the past tense within the relative clause no longer has any c-commanding controller. By default, PRO-ZPs refer to the UT when they have no controller and a past tense chooses any point in the past with respect to the UT. 
Both Enç's and Stowell's theories describe the fact that the past tense in a relative clause behaves as if it is in a simple sentence, whereas the past tense in a complement clause must always refer to the point that precedes the matrix TT. Based on these, it is conceivable that the stimuli in the Complement Clause Experiment (PAST UNDER PAST SENTENCES) are semantically more complex than the stimuli in either the Simple Sentence Experiment or the Relative Clause Experiment.

If children are sensitive to this type of semantic complexity then we predict a contrast between the results of the Simple Sentence Experiment and the Relative Clause Experiment, and the results of the Complement Clause Experiment. This contrast can be observed in two different ways: first, in the percentage of correct responses and second, in the error types for the three conditions.

The second factor that can influence the results of the experiments is the various syntactic positions where a past tense form appears. The experiments in this paper compared three positions: in simple sentences, in complex sentences with complement clauses and in complex sentences with relative clauses. According to Lebeaux (1990, 2000), young children in the face of processing difficulty fail to make use of the rule that adjoins adjuncts, such as relative clauses (Adjoin $\alpha$ ). However, these children have less problems with complement clauses, since these are licensed as arguments of verbs. Lebeaux (1990,2000) distinguishes adjuncts from complements by arguing that adjuncts are not licensed by theta theory and a verb does not subcategorize them. The Projection Principle does not call for the adjuncts to be present at all levels. In the Relative Clause Experiment, the stimuli call for Adjoin $\alpha$; by contrast, the other two experiments (the Simple Sentence Experiment and the Complement Clause Experiment) do not call for Adjoin $\alpha$. If syntactic complexity influences children's performance, we should see a clear divergence in the results of the experiments.

The third factor that might influence children's production of past tense is the Lexical Aspect of the verbs used in the stimuli. As briefly discussed in Section 1, Bronckart and Sinclair (1973) show that the trend of the (lexical) Aspect before Tense Hypothesis lasts until the age of 6 in French. We included an equal number of telic and atelic predicates in all three experiments to investigate whether or not the Aspect before Tense Hypothesis is also observed in Dutch with 4-6 year old children.

\section{$3 \quad$ Predictions (by three factors)}

In this section, we will summarize how the three factors discussed above (semantic and syntactic complexity and lexical aspect) can influence children's production data.

The first possible outcome pertains to semantic complexity. If it is difficult to produce a past tense that needs to be anchored to a matrix past tense, then children might perform better in the Simple Sentence Experiment and the Relative Clause Experiment than in the Complement Clause Experiment. In other words, if the semantic complexity solely influences children's performance and if it is easier for children to produce a past tense when it is anchored to the UT, we should observe better performance in the Relative Clause Experiment than in the Complement Clause Experiment although the stimuli involved in experiments are syntactically more complex. Or, it is also possible that children show a certain type of error in the Simple Sentence Experiment and the Relative Clause Experiment and another type of error in the Complement Clause Experiment. However, what is crucial here is there should not be an interaction between children's error rate and error pattern as in the third possible outcome. 
The second possible outcome pertains to sentence complexity concerning the rule: Adjoin $\alpha$. The term "complexity" here is related to the formal syntactic analysis; sentences are considered to be complex if they include embedded CPs and even more if these CPs are adjuncts, as opposed to complements. If this type of complexity interferes with children's ability to provide a correct past tense, then we predict that a significant differences among all three experiments. We should observe better performance in the Simple Sentence Experiment than the Complement Clause Experiment, and better performance in the Complement Clause Experiment than the Relative Clause Experiment. By hypothesis, such difficulty is related to the general processing system, where children find it difficult to perform well in the task if the stimuli are hard to process. We also predict that children might come up with strategies to deal with their difficulty. We should find uniform pattern of errors; for example, children to give infinitive or present forms as their strategy to deal with complex structures involving Adjoin $\alpha$. This prediction does not speak for or against the theory of tense described above.

The third outcome involves an interaction between syntactic and semantic complexity. This would result in children performing in the same manner hierarchically as in the second case (the Simple Sentence Experiment > the Complement Clause Experiment > the Relative Clause Experiment); however, we should see a different error pattern in the Complement Clause Experiment from the Relative Clause Experiment. Children should perform well in the Simple Sentence Experiment, because neither tense anchoring nor sophisticated processing ability is required to interpret a simple sentence. In the Complement Clause Experiment, children should perform worse than in the Simple Sentence Experiment because the stimuli are more complex, and because tense ordering is required. The Relative Clause Experiment should be more difficult still. Children might find adjuncts more difficult to process than complements; however, we might observe the same error pattern between the Simple Sentence Experiment and the Relative Clause Experiment because in both cases, we need to anchor a past tense with respect to the UT.

Finally, if Lexical Aspect of the verbs influences the production data by 4 to 5 -year-olds in Dutch, children should produce past tense more often in telic predicate trials in all three experiments. Table 1 and 2 summarize the predictions discussed so far:

Table 1: The prediction of three factors

\begin{tabular}{|l|l|l|}
\hline factor & hierarchy & error type \\
\hline $\begin{array}{l}\text { semantic } \\
\text { complexity }\end{array}$ & $\begin{array}{l}\text { Simple Sentence Experiment } \\
\text { /Relative Clause Experiment } \\
\text { Experiment Complement Clause }\end{array}$ & $\begin{array}{l}\text { certain type of errors in the Simple } \\
\text { Sentence \& the Relative Clause } \\
\text { Experiments and different type in } \\
\text { the Complement Clause } \\
\text { Experiment. }\end{array}$ \\
\hline $\begin{array}{l}\text { syntactic } \\
\text { complexity }\end{array}$ & $\begin{array}{l}\text { Simple Sentence Experiment } \\
\text { Experiment }>\text { Relative Clause } \\
\text { Experiment }\end{array}$ & $\begin{array}{l}\text { some strategies to deal with } \\
\text { processing difficulty (uniform in } \\
\text { complex trials) }\end{array}$ \\
\hline $\begin{array}{l}\text { lexical } \\
\text { aspect }\end{array}$ & $\begin{array}{l}\text { telic>atelic } \\
\text { (in all experiments) }\end{array}$ & $\begin{array}{l}\text { past tense forms found more with } \\
\text { telic than with atelic predicates }\end{array}$ \\
\hline
\end{tabular}


Table 2: different complexity

\begin{tabular}{|c|c|c|}
\hline complexity type & sentence type & description \\
\hline $\begin{array}{l}\text { (i)semantic } \\
\text { complexity }\end{array}$ & Simple Sentence & $\begin{array}{l}\text { past tense must be interpreted with } \\
\text { respect to the UT }\end{array}$ \\
\hline $\begin{array}{l}\text { (ii)semantic } \\
\text { complexity }\end{array}$ & $\begin{array}{l}\text { complex sentence with } \\
\text { a complement clause }\end{array}$ & $\begin{array}{l}\text { past tense must be interpreted with } \\
\text { respect to the TT1 } \\
\text { ordering restriction between TT1 } \\
\text { and TT2 necessary }\end{array}$ \\
\hline $\begin{array}{l}\text { (iii)semantic } \\
\text { complexity }\end{array}$ & $\begin{array}{l}\text { complex sentence with } \\
\text { a relative clause }\end{array}$ & $\begin{array}{l}\text { past tense must be interpreted with } \\
\text { respect to the UT } \\
\text { No ordering restriction between TT1 } \\
\text { and TT2 necessary }\end{array}$ \\
\hline $\begin{array}{l}\text { (iv)syntactic } \\
\text { complexity }\end{array}$ & Simple Sentence & simple and the easiest \\
\hline $\begin{array}{l}\text { (v)syntactic } \\
\text { complexity }\end{array}$ & $\begin{array}{l}\text { complex sentence with } \\
\text { a complement clause }\end{array}$ & $\begin{array}{l}\text { more complex than (iv) } \\
\text { No need of Adjoin } \alpha\end{array}$ \\
\hline $\begin{array}{l}\text { (vi)syntactic } \\
\text { complexity }\end{array}$ & $\begin{array}{l}\text { complex sentence with } \\
\text { a relative clause }\end{array}$ & $\begin{array}{l}\text { more complex than (iv) } \\
\text { involves Adjoin } \alpha\end{array}$ \\
\hline
\end{tabular}

In the following section, we will introduce the three experiments and discuss which of the possible outcome best explains the results obtained.

\section{$4 \quad$ Simple Sentence Experiment}

The goal of the Simple Sentence Experiment was to determine whether 45 year olds can supply correct verbs with past tense morphology across different predicate types. Only simple sentences were used so that we can later compare the results from the Complement Clause and the Relative Clause Experiments.

\subsection{Method}

\subsubsection{Subjects}

The subjects were twenty two children in total (eleven 4year-olds (from 4;2-4;11 with a mean of 4;7) and eleven 5-year- olds (from 5;1-5;11 with a mean of 5;5)) plus five adult controls ${ }^{5}$. All children were native speakers of Dutch. Subjects were tested in UtrechtNijmegen area basis (elementary) schools.

\subsubsection{Materials}

Each subject received twelve test trials and nine control trials (total of twenty one trials). The twelve test trials included six telic and six atelic predicates listed in Table 3:

5 The results from the five adults were $100 \%$ correct. 
Table 3: The predicates used in the experiments

\begin{tabular}{|l|l|l|l|}
\hline Dutch & English & Telicity & Regular? \\
\hline was groen-gestippeld & was green-dotted & Atelic & irregular \\
\hline had toverkracht & had magic power & Atelic & irregular \\
\hline had honger & was hungry & Atelic & irregular \\
\hline waren verdrietig & was sad & Atelic & irregular \\
\hline een huis bouwden & built a house & Telic & regular \\
\hline een koekje bakte & baked a cookie & Telic & regular \\
\hline huppelde & Hopped & Telic & regular \\
\hline piepte & Beeped & Telic & regular \\
\hline
\end{tabular}

\subsubsection{Procedure}

An Elicited production task (modeled on van Hout (1996) (following Berko (1958)) was used to elicit a certain sentence type (here, a simple sentence) involving telic or atelic predicates. Two experimenters were involved in the experiment. The first experimenter told a story using pictures from a picture book; the second experiment played the role of a 'forgetful puppet'. After each story, the 'forgetful puppet' related what had happened in the story but sometimes she forgot what she was going to say. Children were asked to help the puppet complete the sentence, or to reward the puppet when she was able to say the whole sentence. Children gave stickers to the puppet when she successfully completed a sentence without help; these completed trials served as filler sentences. We exploited the fact that in Dutch the finite verb appears sentence-finally in embedded sentences. The target is listed in (18) with a picture from the picture book; the intended target verb is given in parentheses:

(18) De kat (vloog)

The cat (flew)

'The cat flew'

One child at a time was tested in a separate room. It took 20 minutes to run each session but children were reminded that they were allowed to go back to their classroom whenever they wanted to. The sample response in this experiment is in (19): ${ }^{6}$ :

(19) Exp 1: this is a story about a boy and a girl. They are going for a walk in the Magic Forest. There are many special things happening there. Look, here, they are getting near to a very old tree. It is a magic tree. The boy and the girl like to dance around the tree. Look, they are done now; they are standing still by the tree.

Exp 2 (a puppet): Ze dansten. (filler)

They danced.

Child: Yes, the puppet gets a reward!

Exp 1: Because of the dancing, the tree is going to sing a song. It is a real Magic Tree!

6 All stories were given in Dutch but here, for convenience, the target sentence is given in Dutch and the rest of the stimuli are given in English. 
Now, the singing is over and the boy and the girl are moving on $^{7}$. (turn the page)

Exp 2: De boom ...ummm...

The tree...ummm...

Child: zong een liedje!

sang a song!

The responses were recorded on an answer sheet as well as audio-taped. It was irrelevant for us to elicit the exact lexical item. We scored a response as 'correct' if it contained a verb with a past tense morphology or a present perfect. $^{8}$ Responses were scored correct even when children morphologically overregularized irregular verbs ${ }^{9}$.

\subsection{Results}

As shown in Figure 1, overall, children performed very well in this experiment. The overall percentage correct was $85.5 \%$. 4year-olds performed $84.85 \%$ correct; surprisingly, 5-yearolds performed a little worse with $79.55 \%$ correct.

Figure 1: Simple Sentence Experiment (Response types given by 4 and 5-year-olds)

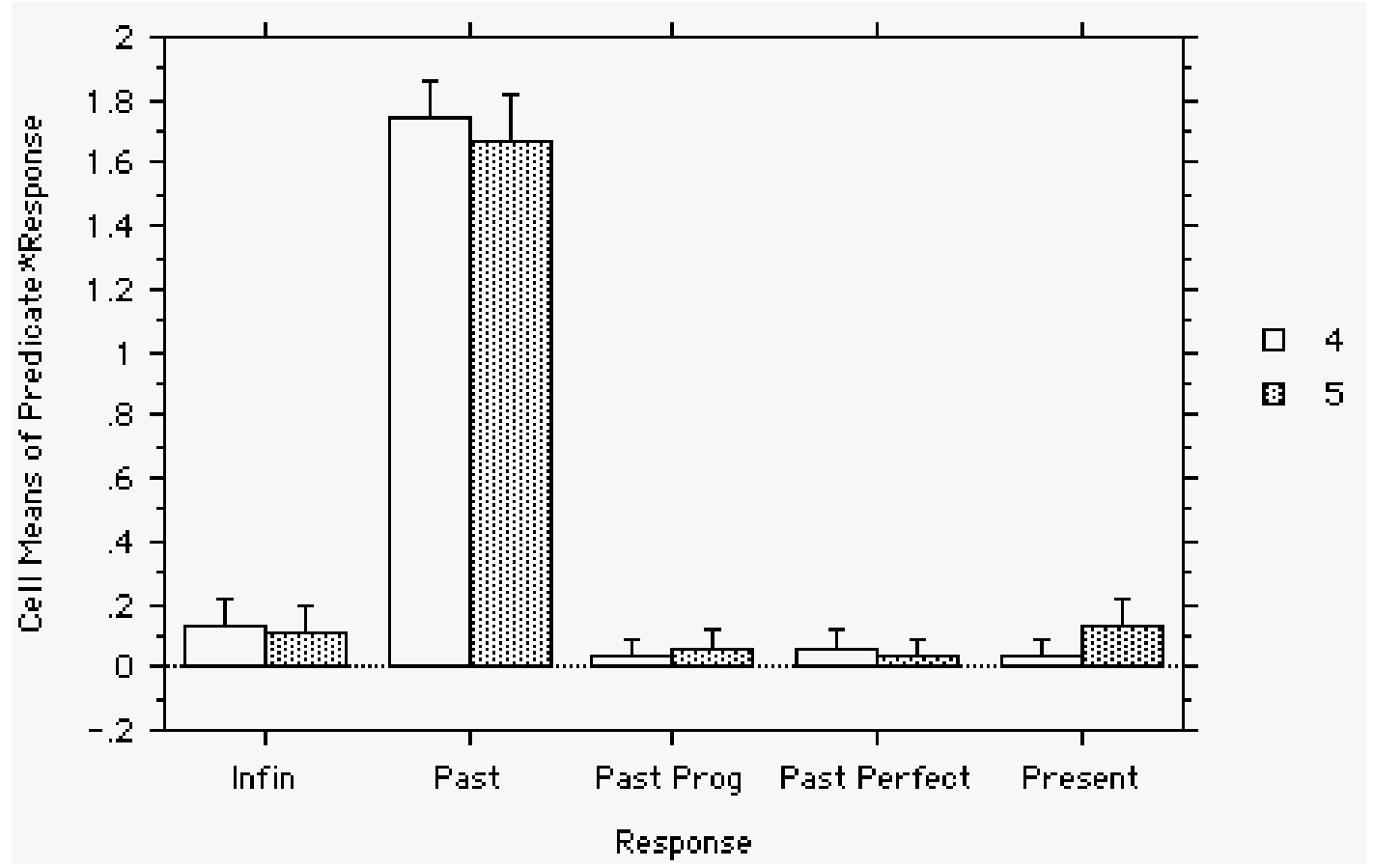

As shown above, most of the errors children made were to produce verbs with an infinitive marking instead of a past tense. Children had most success with accomplishment predicates (95.5\% correct) and the least success with activity verbs (75\% correct). The most common

7 We made it clear that the events were completed and in the past. All stories included the sentence saying "now, they finished ..." or "they are done with..." and we also turned a page to show that the event took place in the past.

8 In Dutch, either a present perfect or a simple past form is used interchangeably for the cases where a simple past is used in English. However, the Dutch children mostly used past tense except for a few cases.

9 The 12 verbs used in the experiment included 4 regular and 8 irregular (as shown in Table 3). Birdsong (p.c) July $2^{\text {nd }}, 2002$ ) suggested that one might expect to see a difference in children's performance depending on whether the verbs are regular or not; however, such a tendency was not observed. 
errors involved producing an infinitive marking with activity verbs (15.9\%) and producing a present tense marking with achievement verbs $(9 \%)$.

\subsubsection{Analysis}

The results of the Simple Sentence Experiment were entered into separate (subjects and items) analyses of variance (ANOVAs). For the subjects ANOVA, there was one betweensubject variable: age (levels=2) and one within-subject variable: telicity (levels $=2$ ). For the items ANOVA, there was one between-cases variable: telicity (levels 2) and one within-cases variable: age 4 or 5 year olds (levels 2). In all cases, the dependent variable was the percentage of correct responses.

\subsubsection{Analyses of the results}

The subject ANOVA revealed no effect of age: $(F(1,21)=.652, p=.429)$. There was a marginal effect of telicity: $(\mathrm{F}(1,21)=3.735, \mathrm{p}=.0675)$ but no interaction between age and telicity: $(\mathrm{F}(1,21)=.031, \mathrm{p}=.8623)$. The item ANOVA revealed no effect of telicity $(\mathrm{F}(1$, $11)=.1217, \mathrm{p}=.2957)$ or age $((\mathrm{F}(1,11)=1.109, \mathrm{p}=.3172)$. There was no interaction between telicity and age: $(\mathrm{F}(1,11)=.023, \mathrm{p}=.8834)$

\subsection{Discussion}

As predicted, the Simple Sentence Experiment was easy for both 4 and 5-year-olds. They managed to produce correct past tense markings in telic as well as atelic trials. Occasional errors included supplying various markings such as infinitive, past progressive, past perfect and present; however, infinitives were the most common mistake. There was no trend of Aspect before Tense observed in the responses.

\section{$5 \quad$ Complement Clause Experiment}

In the second experiment, we investigated whether children find it more difficult to supply correct verbs with past tense markings in a complement clause. As discussed in Section 3, children might find this experiment more difficult than Simple Sentence Experiment, either because the structure involved is more complex, or because children have to possess knowledge of the temporal anchoring mechanism between a main and an embedded finite verb, or for both of these reasons.

In principle, the presence of a matrix predicate with a past tense could facilitate or hinder correct responses. The presence of a matrix predicate might facilitate a correct response since if children paid attention to the verb form, they would just have to copy the tense to succeed. Alternatively, it could interfere with a correct response if temporal anchoring is difficult, or if children decide that a temporal marking in an embedded clause is not obligatory as discussed concerning the example in (8).

\subsection{Method}

\subsubsection{Subjects}

The subjects were thirteen children (six 4year-olds (from 4;2-4;9 with a mean of 4;7) and seven 5-year-olds (from 5;1-5;11 with a mean of 5;5)) plus five adult controls. Subjects were all native speakers of Dutch and they were tested in Utrecht-Nijmegen area basis (elementary) school. 


\subsubsection{Materials}

The predicates used were identical to those in the Simple Sentence Experiment (six telic and six atelic predicates). The experiment included twenty one total trials (twelve test trials plus nice control trials).

\subsubsection{Procedure}

The procedure was the same as the Simple Sentence Experiment (an elicited production task). As discussed in 4.1.3, the first experimenter told a story using a picture book; however, in this experiment, the first experimenter took a role of the monkey, a storyteller, to elicit a sentence that started with "the monkey said that-." We made sure that the differences made between this and the Simple Sentence Experiment were kept to a minimum except that the first experimenter, who told stories to the children, pretended to be a monkey. A sample sentence from this experiment is given in (20):
De aap zei dat het
meisje de trap (op liep)
The monkey said that the girl the stairs up walked
'The monkey said that the girl walked up the stairs.'

This procedure showed more control than the "question-answer" task used in Hollebrandse (1999), in which the child was asked to answer a question such as "what did the monkey say". In such a task, if a child answers "the girl walked up the stairs" or just "walk up the stairs", it is very difficult to tease apart whether children are using direct or indirect speech. In the present experiment, all children were asked to do was to supply a verb; children were not given any freedom to use a "direct" quotation due to the presence of a complementizer: "that" as well as due to the word order. If it is a direct quotation, (20) should look like (21):
(21) De aap zei "het meisje liep de trap op".
The monkey said the girl walked the stairs up

'The monkey said "the girl walked up the stairs".'

A sample response of the Complement Clause Experiment is given in (22):

(22) Exp 1 (a monkey): Look, here is a man. He is a bit sad. But look, he sees a piano and he is happier! He likes pianos very much. (turn the page)

$\begin{array}{rlll}\text { Exp } 2 \text { (puppet): De aap zei dat de man } & \text { verdrietig... } \\ \text { The monkey said that the man } & \text { sad }\end{array}$

Child: was!

Exp 2 (puppet): En de aap zei ook dat de man piano's heel mooi vindt.

And the monkey said also that the man pianos very much liked

'and the monkey also said that the man liked pianos very much.'

Child: Yes, the puppet did a good job this time!

Exp 1 (monkey): Look, he is going toward the piano and he starts to play! He plays a couple of songs. Now he is very happy and walking away. (turn the page)

$\begin{array}{rllll}\text { Exp 2 (puppet): De aap } & \text { zei dat de man } & \text { piano .... } \\ \text { The monkey } & \text { said that the man } & \text { piano .... }\end{array}$

Child: speelde.

played 


\section{$5.2 \quad$ Results}

The overall results in Figure (Total of $79.1 \%$ correct) seem only slightly worse compared to the Simple Sentence Experiment; however, the results look quite different when analysed according to age. (67.86\% correct for 4-year-olds and $83.67 \%$ correct for 5-year-olds).

Figure 3: Complement Clause Experiment (Response types given by 4 and 5-year-olds)

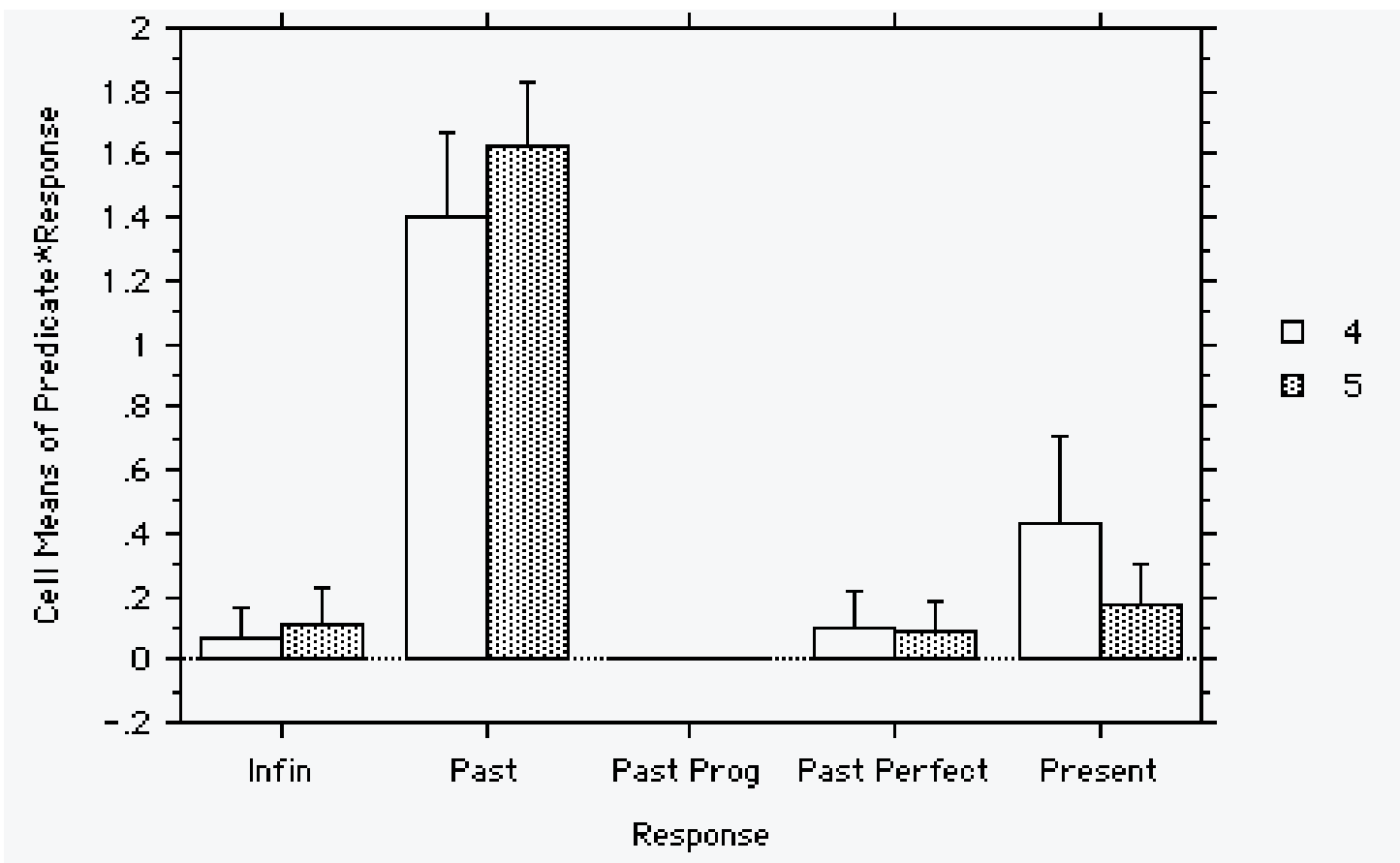

As in the Simple Sentence Experiment, children's errors included supplying various markings:infinitive, past perfect and present tense. Here again, accomplishment predicates produced the best performance ( $82 \%$ correct). Figure 3 makes it clear that the common error that the children made was to supply a present tense marking instead of a past tense marking.

\subsubsection{Analyses of the results}

The subject ANOVA showed that the effect of age was not significant: $(F(1,12)=1.747$, $\mathrm{p}=.2061)$; the effect of telicity was also not significant: $(\mathrm{F}(1,12)=1.173, \mathrm{p}=.2959)$. There was an interaction between age and telicity: $(\mathrm{F}(1,12)=7.27, \mathrm{p}=.0166)$. The item analysis showed an effect of telicity: $(\mathrm{F}(1,11)=8.115, \mathrm{p}=.0173)$. The effect of age was marginally significant: $(\mathrm{F}(1,11)=3.817, \mathrm{p}=.0793)$; however, an interaction between telicity and age was not significant: $(\mathrm{F}(1,11)=.603, \mathrm{p}=.4553)$.

\subsection{Discussion}

The results of this experiment diverged from that of the Simple Sentence Experiment in two ways. First, overall, the younger children performed worse in this experiment compared to the Simple Sentence Experiment. Second, the error pattern in Figure 3 shows that most of the errors (up to $33 \%$ for stative predicates, among 4-year-olds) included the production of present tense forms. This contrasts with the error pattern seen in the Simple Sentence Experiment, where most errors were infinitival forms.

There are at least two possible interpretations of the frequent usage of a present tense in this experiment. The first interpretation is related to the difference between so-called Sequence of Tense and non-Sequence-of-Tense languages and how they represent an overlapping 
interpretation. As already discussed in Section 3, in Dutch and English (SOT languages) an embedded past tense with a stative predicate is ambiguous:

(23) John said that Bill was happy.

(24) Jan zei dat Bill gelukkig was.

In (23) and (24), there is a reading where Bill was happy at the time of John's saying so (overlapping) or Bill was happy before John said so (real past). Non-SOT languages (Hebrew, Japanese, Polish, Russian and others), however, do not have an overlapping reading in PAST UNDER PAST SENTENCES (see (25)):

(25) John-wa Bill-ga shiawase-datta to itta

John-Top Bill-Nom happy-was that said

(25) only has a real past interpretation (where Bill was happy before John said so).

There have been many proposals how this difference arises (see Enç (1987), Ogihara (1996), Stowell (1996) among others). Stowell (1996), for example, takes a lexical view and argues that English past tense is ambiguous between "real" and "null" past; however, Japanese past is a real past.

According to the Semantic Subset Principle as interpreted by Crain and Lillo-Martin (1998), it is conceivable that English and Dutch children start out with the grammar where past tense is "real" as in Hebrew, Japanese, Polish, or Russian. This could explain why Dutch children used present tense in the Complement Clause Experiment in an overlapping scenario (see (22)). For young Dutch children, the past tense strictly means "past" as in simple sentences and they use a present tense to represent overlapping interpretation. Later, Dutch children find out in certain syntactic positions the past tense is ambiguous between "real" and "null" past through positive data; they start using past tense more often in the Complement Clause Experiment when they reach 5 years old (see Figure 3). This idea presupposes that 4 yearolds know that this is a complex structure and that the first past tense c-commands the second past tense but what they do not know is the ambiguity of the past tense morpheme. If 4-yearolds do not know that the stimuli in the Complement Clause Experiment are complex and involve c-command, then there is no account for the difference in their responses in the Simple Sentence Experiment and Complex Clause Experiment. It should not be surprising even if children use more infinitive markings in Complex Clause Experiment.

Notice that it cannot be that children incorrectly expect it to have only one tense in a complex sentence (compatible with the examples in (8)). This possibility does not hold because children are using present tense markings in an embedded clause instead of infinitive. Moreover, the children did not just copy the tense of a matrix predicate.

\section{Relative Clause Experiment}

In the final experiment, we tested another type of complex sentence, this time involving a relative clause. The stimuli used here are syntactically more complex than the ones in the Complement Clause Experiment because they involve an adjunction structure. As discussed above, Lebeaux $(1990,2000)$ observes that children's grammars are different from adults' with respect to the rules governing adjunction (Adjoin $\alpha$ ). Lebeaux seeks to account for the fact that young children face problems in interpreting relative clauses reported in Tavakolian 
(1978). Tavakolian shows that children between 3;0 and 5;6 tend to interpret sentences such as (26) as though they were conjoined clauses as in (27):

(26) The sheep kissed the monkey who tickled the rabbit.

(27) The sheep kissed the monkey and tickled the rabbit.

Lebeaux $(1990,2000)$ proposes that children have a problem with rule Adjoin- $\alpha$; as a consequence, they treat all adjunct clauses as conjuncts. If children have a problem with " Adjoin- $\alpha "$, then they should face some difficulty in this experiment.

\subsection{Method}

\subsubsection{Subjects}

The subjects were thirteen children (six 4 year-olds (from 4;6-4;11 with mean of 4;7) and seven 5-year-olds (from 5;1-5;11 with a mean of 5;6)) plus five adult controls. Subjects were all native speakers of Dutch and they were tested in Utrecht-Nijmegen area basis (elementary) school.

\subsubsection{Materials}

The predicates used were identical to those in the Simple Sentence Experiment and the Complement Clause Experiment (twelve different predicates-two from six different predicate types). The experiment included twenty one total trials (twelve test trials plus nine control trials).

\subsubsection{Procedure}

The procedure was the same as in the Simple Sentence Experiment and the Complement Clause Experiment. The first experimenter told a story using a picture book; and the second experimenter played a role of a forgetful puppet. The children were encouraged to help the forgetful puppet. There was no difficulty in eliciting the target predicates. A sample sentence from this experiment is given in (28):

(28) Er was een heel rare hond die groen gestippeld (was).

There was a very strange dog that green dotted was

'There was a very strange dog that was dotted green.'

The experiment proceeded as in (29):

(29) Exp 1: The boy and the girl are walking in the magic forest and look, there is a very weird dog! "I am green - dotted!" says the dog. Then he disappears through the trees. (turn the page)

Exp 2 (puppet): Er was een heel rare hond die groen gestippeld...

There was a very strange dog that green striped...

"There was a very strange dog that ... green striped."

Child: was!

Exp 1: They see a dwarf in the grass. He says: "I am building a house. Can you give me a hand? It is almost finished." "Come on, let's help him" says the girl to the boy.

Exp 2 (puppet): I know, the boy and the girl helped the dwarf.

Child: Yes! You did well so you get a sticker! 
Exp 1: Now they are finished building the house. The dwarf house is finished; the boy and the girl are walking on. (turn the page)

Exp 2 (puppet): $\quad$ De jongen em het meisje zagen de kabouter die een huis...

The boy and the girl saw the dwarf that a house

Child: bouwde.

"The boy and the girl saw the dwarf that ... a house."

built

\subsection{Results}

The total percentage correct for this experiment was $67.7 \%$, which was the worst among the three experiments introduced in this paper (see Figure 4).

\subsubsection{Analyses of the results}

The subject ANOVA revealed no effect of age: $\mathrm{F}(1,12)=.328, \mathrm{p}=.5753)$. There was no effect of telicity: $\mathrm{F}(1,12)=.081, \mathrm{p}=.78)$ or no interaction between age and telicity: $\mathrm{F}(1,12)=.349$, $\mathrm{p}=.5635)$. An items analysis showed no effect of telicity, age or an interaction between the two.

\subsection{Discussion}

The result of this experiment was different from both in the Simple Sentence Experiment and the Complement Clause Experiment. Neither 4 nor 5-year-olds performed well. The error pattern was also different: there was no production of past progressive or past perfect markings. When children made errors, they used infinitives more often than present tense markings as they did in the Simple Sentence Experiment (see Figure 4). 


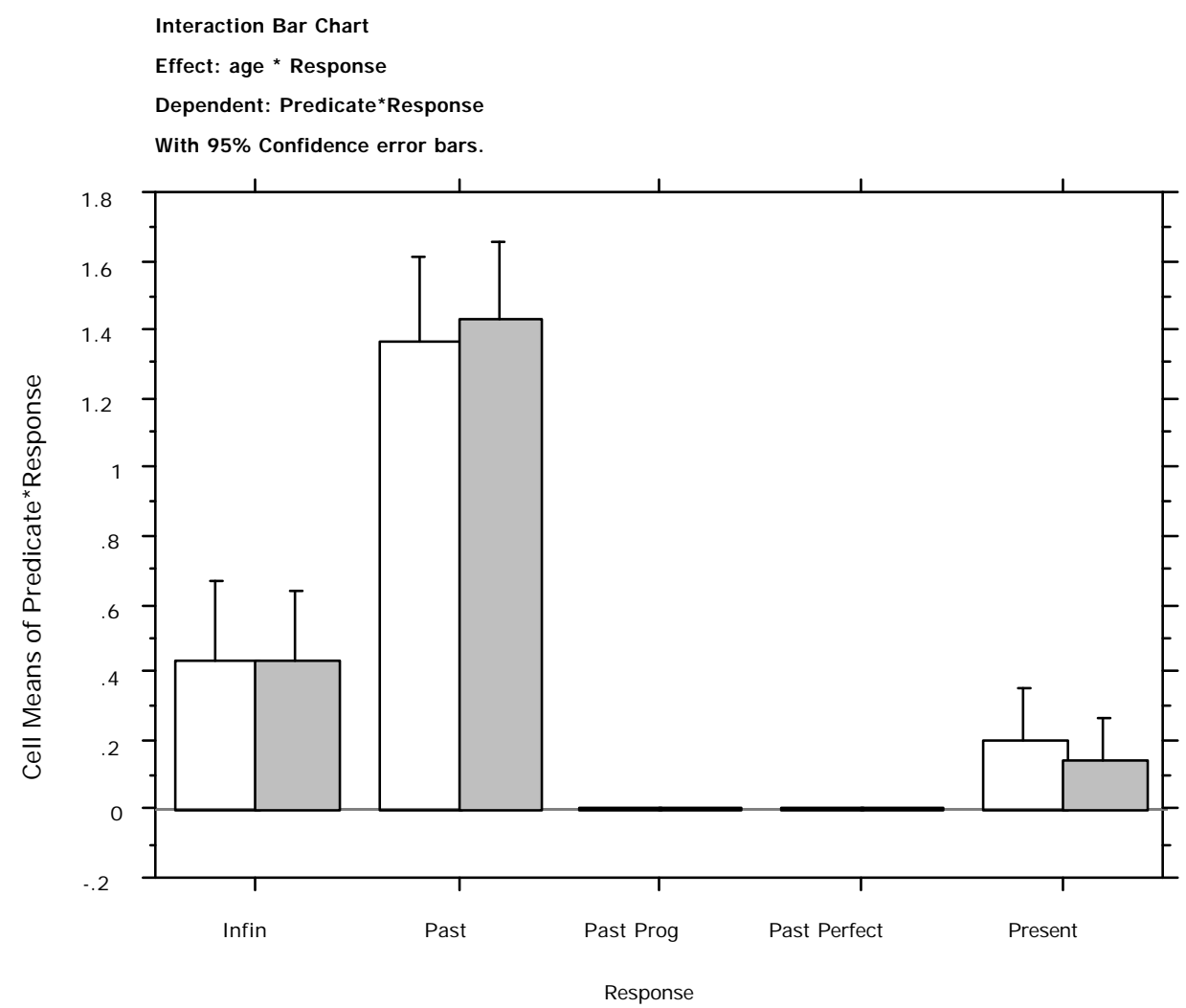

\section{$7 \quad$ General Discussion}

\subsection{Overall results}

The results of the three experiments were entered into one meta-analysis of Subjects and Items ANOVAs. For the subjects ANOVAs, there were two between-subject variables: age (levels=2) and experiment (levels=3) and one within-subject variable: telicity (levels =2). For the items ANOVAs, there was one between-cases variable: telicity (levels=2) and two withincases variable: age 4 or 5 year olds (levels=2) and experiment (levels=3). In all cases, the dependent variable was the proportion of correct responses.

\subsubsection{Analyses of the results}

The subject ANOVA revealed no effect of age: $(\mathrm{F}(2,47)=1.502, \mathrm{p}=.2272)$ but there was a marginal effect of experiment (on correctness): $(\mathrm{F}(2,47)=2.838, \mathrm{p}=.0698)$. There was no effect of telicity: $(\mathrm{F}(2,47)=.028, \mathrm{p}=.8682)$. There was a marginal interaction of experiment and age $)$ : $(\mathrm{F}(2,47)=2.535, \mathrm{p}=.0914)$. The items ANOVA revealed no effect of experiment: $(\mathrm{F}(2,34)=2.319, \mathrm{p}=.1147)$ or telicity: $(\mathrm{F}(2,34)=2.013, \mathrm{p}=.9915)$.

\subsection{Discussion}

The results of the three experiments (see Figure 5) suggest that both structural complexity and temporal complexity influence children's performance. Both 4 and 5-year-olds performed well in the Simple Sentence Experiment; only 5-year-olds performed well in the Complement 
Clause Experiment, while neither 4 nor 5-year-olds performed well in the Relative Clause Experiment.

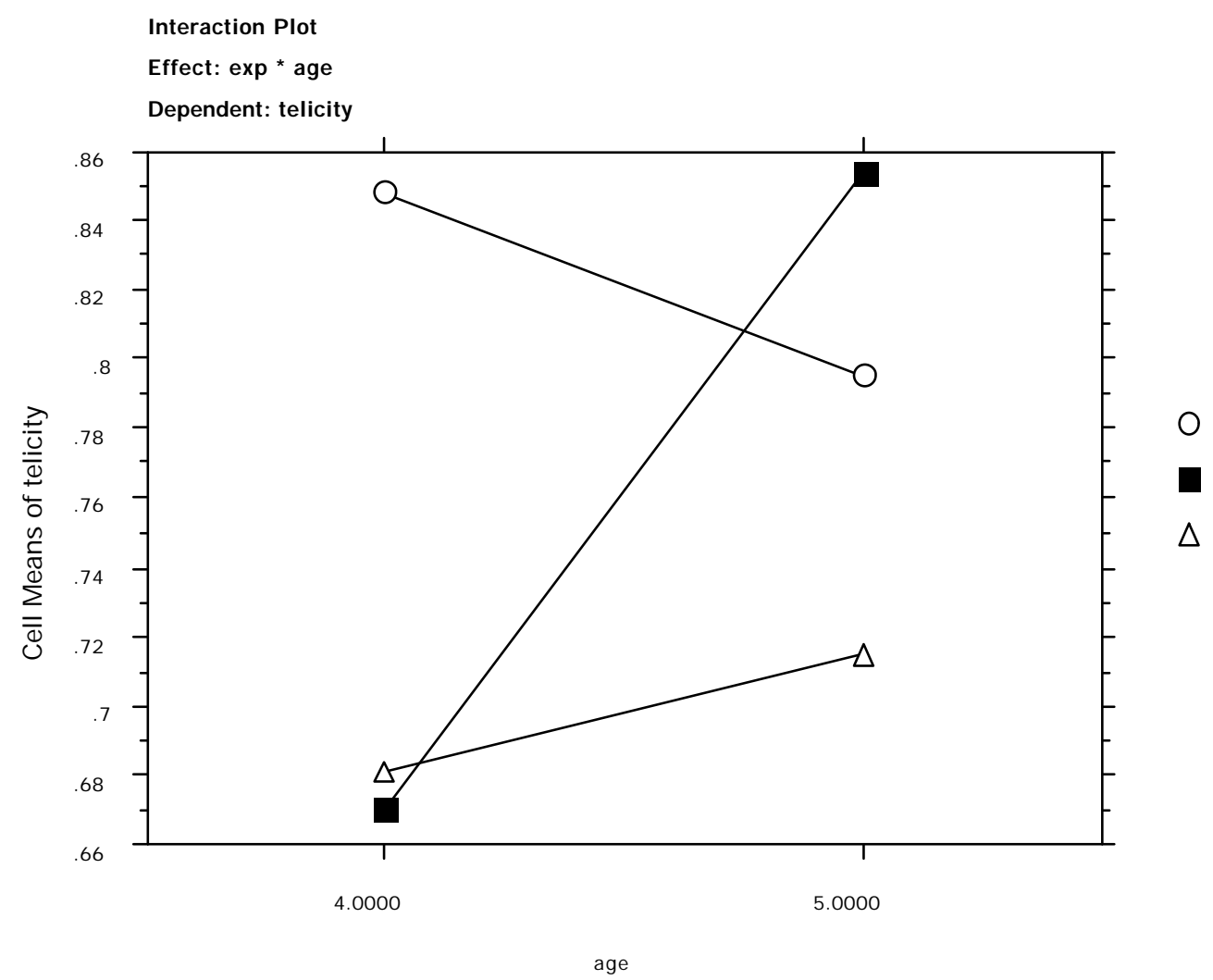

Figure 5: 3 experiments combined (Response types given to different predicate types)

The Relative Clause Experiment was most difficult because it included a CP adjunct. As discussed in Section 5.3, the drastic difference on responses given by 4-year-olds and 5-year olds on the Complement Experiment is best explained by the lexical learning of a past tense taking place between 4 and 5 years of age. Temporal complexity influenced children's production of infinitive verbs in the Simple Sentence and the Relative Clause Experiments. 
Besides the structural influence, we investigated whether Aspect before Tense hypothesis was observed with 4 and 5-year-old Dutch children (as found in Bronckart and Sinclair (1973). There was no effect of telicity in the analyses; Table 4 shows the contrast between the proportion of correct responses in telic and atelic trials and Figure 6 represents the contrast graphically:

Table 4: Percentage correct for telic vs. atelic predicates

\begin{tabular}{|l|l|l|}
\hline & telic & atelic \\
\hline $\begin{array}{l}\text { Simple Sentence } \\
\text { Experiment }\end{array}$ & 86.4 & 80.9 \\
\hline $\begin{array}{l}\text { Complement } \\
\text { Clause Experiment }\end{array}$ & 74.4 & 85.6 \\
\hline $\begin{array}{l}\text { Relative Clause } \\
\text { Experiment }\end{array}$ & 64.1 & 73.08 \\
\hline
\end{tabular}

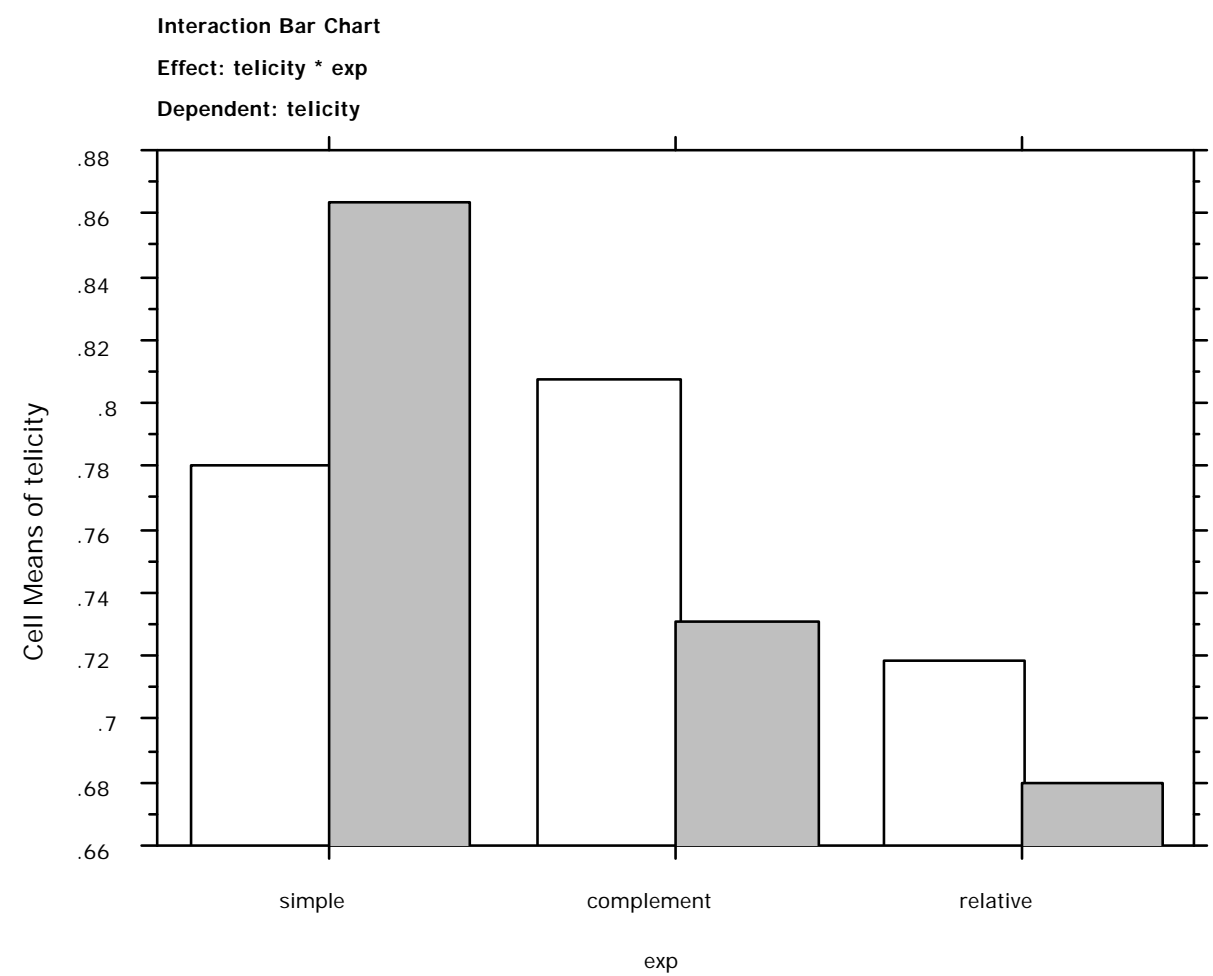

Figure 6: Interaction between Telicity and Experiment (3 experiments combined)

If the effects of Aspect before Tense hypothesis are still observed in this age group, we would predict that children might give correct answers more often with telic predicates ${ }^{10}$. As Table 4 and Figure 6 make clear, children performed slightly better with telic predicates in the Simple

10 In the experiments reported here, the punctual predicates behaved in a strange way. Shirai and Andersen (1995) report that children mainly use a progressive morpheme with punctual predicates in English. The representative utterances from Naomi are something like (i):

(i) Punctual verbs: flopping around, ju mping

However, Dutch children tested here produced many instances of past perfect with punctual predicates. This goes against the prediction considered in the Introduction where 4 and 5-year-old Dutch children show an effect of the Aspect before Tense hypothesis. 
Sentence Experiment; however, the reverse was true in the Complement Clause and the Relative Clause Experiments. We conclude that Telicity did not influence the performance of the Dutch children in these experiments with this age group. Other characteristics of the verbs such as regular vs. irregular; frequent vs. infrequent did not influence children's performance at all (see Appendix).

Figure 7 shows the results classified according to Vendler's classification. The children performed best with accomplishment and stative predicates but performed relatively poorly with punctual predicates.

Figure 7: 3 experiments combined (Response types given to different predicate types)

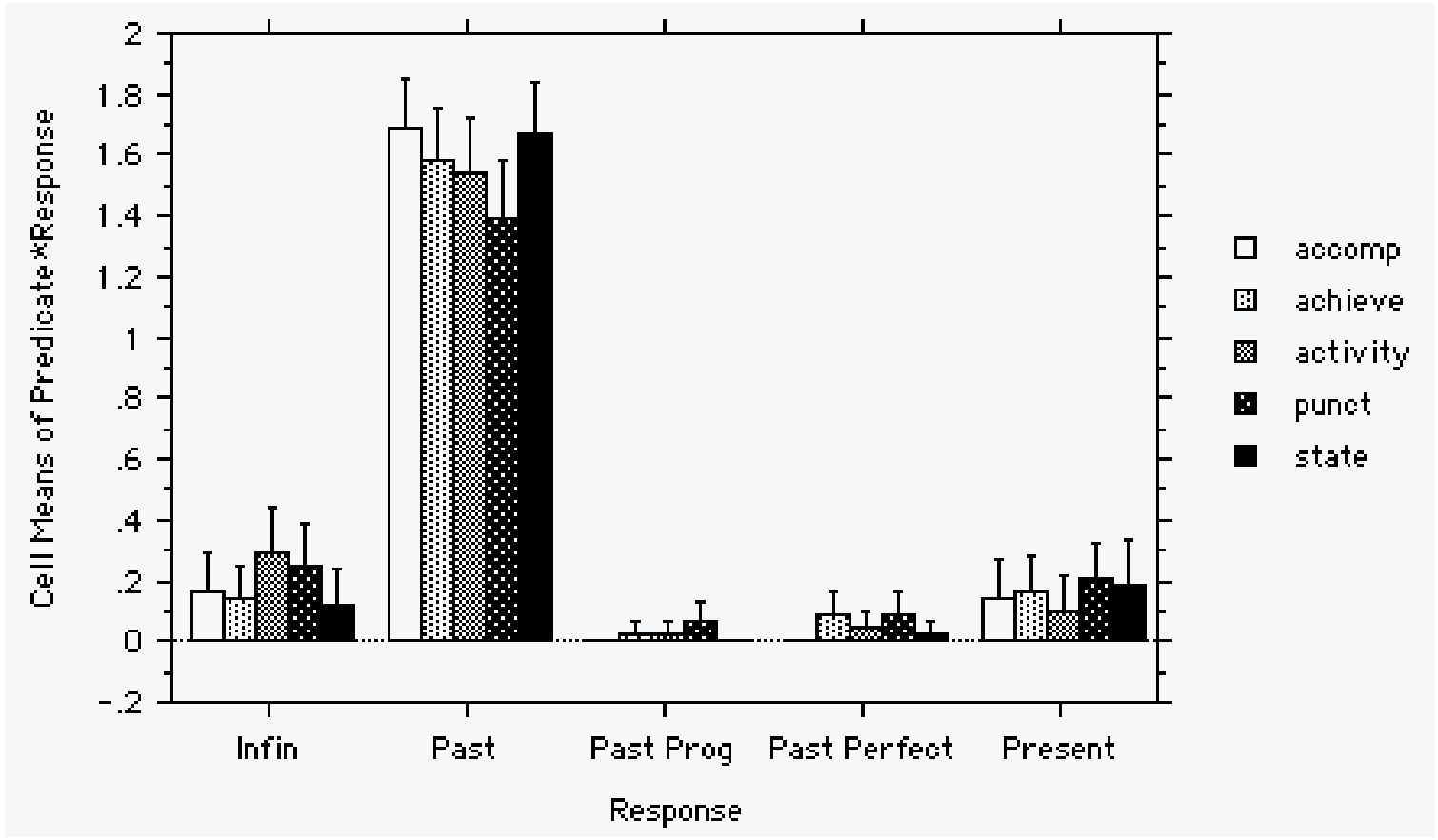

\subsection{Development}

One of our research questions was to investigate whether there is any development in past tense production across different age groups. Figure 5 makes it clear that there is a difference between 4 and 5-year-olds. What distinguishes them is that 4-year-olds do not seem to share an adult interpretation of a past tense. Below, I will explain the results from 4 and 5-year-olds separately. First, 5-year-olds performed well in the Simple Sentence Experiment; they performed much better than 4 year-olds in the Complement Clause Experiment. I proposed that this was the case because 5-year-olds have expanded the semantics of past tense through positive data. Unlike Experiments 1 and 2, 5-year-olds performed poorly in the Relative Clause Experiment. Both syntactic and semantic complexities must have influenced their performance. The children found the stimuli in the Relative Clause Experiment too complex because they involved adjunct CPs. Their error pattern showed the influence of the semantic complexity. When the children relate the TT of an event to the UT, they produce more infinitive markings (the Simple Sentence and the Relative Clause Experiments).

As for 4-year-olds, they performed well only in the Simple Sentence Experiment and not in the Complement Clause and the Relative Clause Experiments. However, as was the case with 5-year-olds, the error patterns in the Complement Clause and the Relative Clause Experiments were very different. The syntactic complexity view alone cannot explain the 
results because it predicts that children should produce the same type of errors across the board. Children must know that there is a difference between the two types of embedded clauses: complements and adjuncts. We raised one explanation that is compatible with these results; 4-year-olds know that the temporal anchoring is necessary in the Complement Clause Experiment but they overproduce a present tense marking because their semantics of a past tense is very restricted and does not include an overlapping interpretation. What is clear is that neither 4 nor 5-year-olds have an adult interpretation of adjunct CPs in the Relative Chuse Experiment.

Based on the results, I suggest that children must go through a two-fold development to perform well in the experiments (or more generally, to correctly produce a verb with a past tense in embedded clauses). First, they must acquire the complex semantics of past tense. A past tense does not always denote the event in the past; a past tense in a complement clause can denote that the events are overlapping. Second, children must possess a matured processing ability for $\mathrm{CP}$ adjuncts (Adjoin $\alpha$ ). They must be able to assign all possible temporal interpretations to complex sentences with relative clauses.

\subsection{Production Errors}

There are two interesting observations in the error analysis. First, in these three experiments, an inverse relationship was observed between how well children performed and how many different types of error they produced. The Simple Sentence Experiment included the lowest error rate (14.5\% incorrect); however, it included four error types: infinitive form, present tense, past progressive and past perfect. The Complement Clause Experiment included more errors (20.9\%) and it included three error types: infinitive form, present tense and past perfect. Finally, the Relative Clause Experiment had the greatest number of errors (30\%) overall, but only two error types: infinitives and present tense forms.

There is no principled reason found for these observations. One possibility, however, is that children were adopting a different strategy in the Relative Clause Experiment. The impression gained is that in the Relative Clause Experiment, the structure was so complex syntactically that children adopted with a specific response strategy to respond in these questions-just by supplying past tense, infinitive or present tense markings (compared to supplying five different forms in the Simple Sentence Experiment). Tables 8 and 9 summarize the discussion in Section 8.

Table 8: The results of the three experiments

\begin{tabular}{|l|l|l|}
\hline age & hierarchy & characteristics \\
\hline 4-year-olds & $\begin{array}{l}\text { Simple Sentence } \\
\text { Experiment>Complement/ } \\
\text { Relative ClauseExperiments }\end{array}$ & $\begin{array}{l}\text { difficulty with an overlapping } \\
\text { interpretation of past tense } \\
\text { difficulty with Adjoin } \alpha \\
\text { different error pattern between } \\
\text { Complement and Relative Clause } \\
\text { Experiments }\end{array}$ \\
\hline 5-year-olds & $\begin{array}{l}\text { Simple Sentence } \\
\text { /Complement Clause } \\
\text { Experiments > Relative } \\
\text { Clause Experiment }\end{array}$ & $\begin{array}{l}\text { difficulty with Adjoin } \alpha \\
\text { different error pattern between } \\
\text { Complement and Relative Clause } \\
\text { Experiments }\end{array}$ \\
\hline
\end{tabular}


Table 9: different complexity types and the results

\begin{tabular}{|c|c|c|c|}
\hline $\begin{array}{l}\text { complexity } \\
\text { type }\end{array}$ & $\begin{array}{l}\text { sentence } \\
\text { type }\end{array}$ & description & $\begin{array}{l}\text { How are comlexity } \\
\text { types manifested in the } \\
\text { results? }\end{array}$ \\
\hline $\begin{array}{l}\text { (i) semantic } \\
\text { complexity }\end{array}$ & $\begin{array}{l}\text { Simple } \\
\text { Sentence }\end{array}$ & $\begin{array}{l}\text { past tense must be } \\
\text { interpreted with respect } \\
\text { to the UT }\end{array}$ & $\begin{array}{l}40.6 \% \text { of the overall } \\
\text { errors were to give } \\
\text { infinitive markings }\end{array}$ \\
\hline $\begin{array}{l}\text { (ii) semantic } \\
\text { complexity }\end{array}$ & $\begin{array}{l}\text { complex } \\
\text { sentence } \\
\text { with a } \\
\text { complement } \\
\text { clause }\end{array}$ & $\begin{array}{l}\text { past tense must be } \\
\text { interpreted with respect } \\
\text { to the TT1 } \\
\text { ordering restriction } \\
\text { between TT1 and TT2 } \\
\text { necessary }\end{array}$ & $\begin{array}{l}\text { Errors included many } \\
\text { present tense markings } \\
(39.3 \%)\end{array}$ \\
\hline $\begin{array}{l}\text { (iii) } \\
\text { semantic } \\
\text { complexity }\end{array}$ & $\begin{array}{l}\text { complex } \\
\text { sentence } \\
\text { with } \\
\text { relative } \\
\text { clause }\end{array}$ & $\begin{array}{l}\text { past tense must be } \\
\text { interpreted with respect } \\
\text { to the UT } \\
\text { No ordering restriction } \\
\text { between TT1 and TT2 } \\
\text { necessary }\end{array}$ & $\begin{array}{l}66.6 \% \text { of the overall } \\
\text { errors were to give } \\
\text { infinitive markings }\end{array}$ \\
\hline $\begin{array}{l}\text { (iv) } \\
\text { syntactic } \\
\text { complexity }\end{array}$ & $\begin{array}{l}\text { Simple } \\
\text { Sentence }\end{array}$ & simple and the easiest & $85.5 \%$ correct \\
\hline $\begin{array}{l}\text { (v) syntactic } \\
\text { complexity }\end{array}$ & $\begin{array}{l}\text { complex } \\
\text { sentence } \\
\text { with a } \\
\text { complement } \\
\text { clause }\end{array}$ & $\begin{array}{l}\text { more complex than (iv) } \\
\text { No need of Adjoin } \alpha\end{array}$ & $78.8 \%$ correct \\
\hline $\begin{array}{l}\text { (vi) } \\
\text { syntactic } \\
\text { complexity }\end{array}$ & $\begin{array}{l}\text { complex } \\
\text { sentence } \\
\text { with } \\
\text { relative } \\
\text { clause }\end{array}$ & $\begin{array}{l}\text { more complex than (iv) } \\
\text { involves Adjoin } \alpha\end{array}$ & $67.7 \%$ correct \\
\hline
\end{tabular}

\section{Conclusion}

The experiments reported here shows that both semantic and structural complexity greatly influenced children's past tense production. The structural complexity here is not based on the number of subjects and predicates but whether or not a CP is a complement or an adjunct. The varying patterns of errors across sentence-type were also revealing. For the Complement Clause Experiment, where children used a relatively high proportion of present tense forms, we discussed the theoretical possibility that Dutch children initially have more restricted semantics of the past tense as found in other non-SOT languages.

Furthermore, the results showed that the aspectual property of telicity does not influence children's production of a past tense at this stage of the development unlike the findings in 
Bronckart and Sinclair (1973). Also, other characteristics of the verbs such as regularity or frequency did not influence the results at all.

Finally, the systematicity of children's production errors casts doubt on the claim that children form their grammar only through the input. If children learn when to supply a past tense just from the input, there is no account for why the children used a present tense so often in the Complement Clause Experiment and not in the Relative Clause Experiment.

\section{References}

Abusch, D. (1988) Sequence of Tense, Intensionality and Scope. In Hagit Borer (ed.) Proceedings of the $7^{\text {th }}$ West Coast Conference on Formal Linguistics, 1-14. Stanford, CA: The Stanford Linguistics Association.

Antinucci, F, and R. Miller. (1976) How children talk about what happened. Journal of Child Language 3. 169189.

Banfield, A. (1984) Unspeakable Sentences. Boston: Routledge and Kegan Paul Ltd.

Berko, J. (1958) The child's learning of English morphology. Word, 14, 150-177.

Bloom, L, K. Lifter and J. Hafis (1980) Semantics of verbs and the development of verb inflection in child language. Language 56: 386-412.

Bowerman, M. (1979) The Acquisition of Complex Sentences. In P. Fletcher and M.Garman (eds.), Language Acquisition Studies in First Language Development, 285-306. Cambridge: Cambridge University Press.

Bronckart, J.P. and H. Sinclair (1973) Time, tense and aspect Cognition 2, pp107-130.

Crain, S. and D. Lillo-Martin. (1998) An Introduction to Linguistic Theory and Language Acquisition. Malden, Blackwell Publishers.

Enç, M. (1987) Anchoring Conditions for Tense. Linguistic Inquiry, vol 18, Number 4 633-657.

Hollebrandse, B. (1999) The Acquisition of Sequence of Tense. Doctoral thesis

University of Massachusetts, Amherst.

Van Hout, A. (1996) Event semantics of verb frame alternations : a case study of Dutch and its acquisition. Doctoral thesis, Tilburg: Katholieke Universiteit Brabant.

Klein, W. (1994) Time in Language. London: Routledge.

Lebeaux, D. (1990) The grammatical nature of the acquisition sequence. in L. Frazier, and J. de Villiers, (eds.) Language Processing and Language Acquisition. Dordrecht: Kluwer Academic Publishers.

Lebeaux, D. (2000) Language Acquisition and the Form of the Grammar. Philadelphia: John Benjamins Publishing Company.

MacWhinney, B, and C. Snow (1990) The Child Language Data Exchange System: An update. Journal of Child Language 17. 457-472.

Marcus, G, S. Pinker, M. Ullman, M. Hollander, J. Rosen and F. Xu (1992) Overregularization in Language Acquisition. Monographs of the Society for Research in Child Development Vol. 57, No.4. Chicago: The University of Chicago Press.

Ogihara, T. (1996) Tense, Attitudes and Scope, Dordrecht: Kluwer Academic Publishers.

Olsen, M and A. Weinberg (1999) "Innateness and the Acquisition of Grammatical Aspect Via Lexical Aspect", Proceedings of the 24th annual Boston University Conference on Language Development, Cascadilla Press, Somerville.

Phillips, C (1995) "Syntax at age two: cross-linguistic differences" In: C. Schütze, J. Ganger \& K. Broihier (eds), Papers on Language Processing and Acquisition. MITWPL 26, 225-282.

Rizzi, L (1994) Some notes on linguistic theory and language development: the case of root infinitives. Language Acquisition 3, 371-393.

Shirai, Y, and R. Andersen (1995) The Acquisition of Tense-Aspect Morphology: A Prototype Account. Language vol. 71 number 4: 743-762.

Stowell, T. (1996) The Phrase Structure of Tense. In Phrase Structure and the Lexicon: 277-291. M. Simons and T. Galloway (eds.). Dordrecht: Kluwer.

Tavakolian, S. (1978) Structural Principles in the Acquisition of Complex Sentences. Ph.D. Dissertation, University of Massachusetts. 


\section{Appendix 1}

I. Results of Experiments 1-3 (Vendler's predicate types)

Table 1: Simple Sentence Experiment (percentage correct)

\begin{tabular}{|l|l|l|l|l|l|l|}
\hline & accomp & achieve & activity & punctual & states & total \\
\hline $\begin{array}{l}\text { Simple Sentence } \\
\text { Experiment }\end{array}$ & 95.5 & 79.5 & 75.0 & 84.1 & 93.2 & 85.5 \\
\hline
\end{tabular}

Table 2: Complement Clause Experiment (percentage correct)

\begin{tabular}{|c|c|c|c|c|c|c|}
\hline & accomp & achieve & activity & punctual & states & total \\
\hline $\begin{array}{l}\text { Complement } \text { Clause } \\
\text { Experiment }\end{array}$ & 84.1 & 77.3 & 86.4 & 59.1 & 88.6 & 78.8 \\
\hline
\end{tabular}

Table 3: Relative Clause Experiment (percentage correct)

\begin{tabular}{|l|l|l|l|l|l|l|}
\hline & accomp & achieve & activity & punctual & states & total \\
\hline $\begin{array}{l}\text { Relative c Clause } \\
\text { Experiment }\end{array}$ & 65.4 & 76.9 & 76.9 & 61.5 & 69.2 & 68 \\
\hline
\end{tabular}

II. Results of three Experiments (response types (\%))

\begin{tabular}{|l|l|l|l|l|l|}
\hline & infinitive & past & $\begin{array}{l}\text { past } \\
\text { progressive }\end{array}$ & past perfect & present \\
\hline $\begin{array}{l}\text { Simple Sentence } \\
\text { Experiment }\end{array}$ & 5.91 & 85.45 & 2.27 & 2.27 & 4.09 \\
\hline $\begin{array}{l}\text { Complement } \\
\text { Clause } \\
\text { Experiment }\end{array}$ & 7.95 & 78.79 & 0 & 4.92 & 8.33 \\
\hline $\begin{array}{l}\text { Relative Clause } \\
\text { Experiment }\end{array}$ & 21.53 & 67.69 & 0 & 0 & 8.46 \\
\hline
\end{tabular}


III. Error types (different predicates)

\begin{tabular}{|l|l|lllll|}
\hline & verb type & infinitive & past & past prog & past perf & present \\
\hline Simple & accomp & 0 & 95.45 & 0 & 0 & 4.55 \\
Expence & achieve & 4.54 & 79.55 & 2.27 & 4.55 & 9.09 \\
& activity & 15.9 & 75 & 2.27 & 4.54545 & 2.27 \\
& punctual & 6.82 & 84.1 & 6.82 & 0 & 2.27 \\
& states & 2.27 & 93.18 & 0 & 2.27 & 2.27 \\
\cline { 2 - 7 } & total & 5.91 & 85.45 & 2.27 & 2.27 & 4.09 \\
\hline Complement & accomp & 5.55 & 82.1 & 0 & 4.55 & 7.82 \\
Experiment & achieve & 21.45 & 75.27 & 0 & 0 & 3.27 \\
& activity & 5.55 & 75.27 & 0 & 13.64 & 5.55 \\
& punctual & 5.55 & 84.36 & 0 & 0 & 10.1 \\
\cline { 2 - 7 } & states & 12.36 & 57.1 & 0 & 11.36 & 19.18 \\
\cline { 2 - 7 } & total & 7.27 & 78.83 & 0 & 0 & 14.09 \\
\hline Relative Clause & accomp & 7.95 & 78.79 & 0 & 4.92 & 8.33 \\
& achieve & 26.92 & 65.38 & 0 & 0 & 7.69 \\
& activity & 15.38 & 76.92 & 0 & 0 & 7.69 \\
& punctual & 23.08 & 76.92 & 0 & 0 & 0 \\
& states & 26.92 & 50 & 0 & 0 & 11.54 \\
\cline { 2 - 7 } & total & 17.38 & 67.73 & 0 & 0 & 15.38 \\
\hline
\end{tabular}

\section{Frequency of stimuli ${ }^{11}$}

The utterances by two Dutch children in the CHILDES database (van Kampen corpus) (MacWhinney and Snow (1990)) were searched to see how frequent the verbs used in the experiments are. We searched for all possible forms of the verbs.

\begin{tabular}{|l|l|}
\hline verb & frequency \\
\hline bake & 101 \\
\hline beep & 11 \\
\hline build & 58 \\
\hline fly & 151 \\
\hline have & 2153 \\
\hline hop & 1 \\
\hline be & 5379 \\
\hline jump & 23 \\
\hline sing & 39 \\
\hline walk & 77 \\
\hline
\end{tabular}

The nonparametric correlational analysis (Spearman's Rho) showed no effect of frequency on the proportion of correct responses ( $\mathrm{p} .=.291)$

\footnotetext{
${ }^{11} \mathrm{I}$ am grateful for Birdsong (p.c.) for raising this point about frequency.
} 
Appendix 2: List of fillers

\section{INTRODUCTION (PICTURE 0)}

This is a story about a boy and a girl. They are going for a walk in the Magic Forest. There are very special things happening there. Now they are on their way.

\section{F. Puppet: They went for a walk}

\section{PICTURE 2}

Now they are getting to a very old tree. It is a magic tree. The boy and the girl dance around it. When they are done, they are standing still again.

\section{F. Puppet: They danced.}

\section{PICTURE 4}

The boy and the girl are walking on. They hop on one leg.

F. Puppet: He hopped (on one leg)

\section{PICTURE 5}

There is a field (of grass). There is a unicorn standing in it, and he doesn't look happy. "How sad, he cries!" says the boy to the girl.

\section{F: Puppet: The unicorn cried.}

\section{PICTURE 6}

Now they are getting to a very high tree. You can climb it. When you're at the top, you can see everything that is happening in the forest.

F. Puppet: On the top they saw everything that happened.

\section{PICTURE 7}

They see a dwarf, in the grass. He says: "I am building a house. Can you give me a hand?

It is almost finished." "Come on, let's help him" says the girl to the boy.

F. Puppet:They helped the dwarf..

\section{PICTURE 9}

Over there are two dwarfs. They are clapping their hands. Suddenly, they stop.

F: Puppet: The dwarfs clapped their hands

\section{PICTURE 11}

In front of the boy and the girl is a squirrel. The squirrel climbs high in the ladder-tree.

F:Puppet: The squirrel climbed high in the tree

PICTURE 12

The boy and the girl are getting to the edge of the forest. It was very nice in the Magic Forest, but now they are going home, to tell about the beautiful things they saw in the forest.

F. Puppet: The boy and the girl went home. 